\title{
The Impact of International Risk on Financial Sector
}

\author{
Adel Al Khattab ${ }^{1}$, Mahmaod Al-Rawad ${ }^{1}$, Muhammad Alalaya ${ }^{2} \&$ Khamis Al-Khattab $^{3}$ \\ ${ }^{1}$ Department of Accounting, College of Business School, Al-Hussain Bin Talal University, Ma'an, Jordan \\ ${ }^{2}$ Department of Economics, College of Business School, Al-Hussain Bin Talal University, Ma'an, Jordan \\ ${ }^{3} \mathrm{Ph} . \mathrm{D}$ Student, Ma'an, Jordan \\ Correspondence: Adel Al Khattab, Department of Accounting, College of Business School, Al-Hussain Bin \\ Talal University, Ma’an, Jordan. Tel: 962-777-640-240. E-mail: adel.alkhattab@yahoo.co.uk
}

Received: January 17, 2015

Accepted: February 2, $2015 \quad$ Online Published: February 25, 2015

doi:10.5539/ibr.v8n3p165

URL: http://dx.doi.org/10.5539/ibr.v8n3p165

\begin{abstract}
Although the MENA is considered a high-risk region, the effects of the political risk on business, in particular financial sector, have not received enough attention in previous studies. This paper, therefore, critically examines international risk affecting the financial sector in Jordan. Such an investigation and the institutions' responses to international risks may compensate the previous gap. In line with the aim of this paper, the phenomenology philosophy was adopted and the inductive approach was followed. The entire target population of the 64 financial institutions which are listed at Amman Stock Exchange for the year 2013 has been studied. The key risks that have affected the financial institutions operating in Jordan include: the Gulf War, the international financial crisis and the Arab Spring. Not all of the financial institutions, however, are affected equally by these risks. Differences among the financial institutions in risk exposure to these risks arise from the differences of their scope and scale. These differences, therefore, have led to differences in financial institutions' responses. A number of strategies and policies have been adopted. The paper represents one of the first such investigations in the context of Jordan. The research findings provide a review and understanding of how financial institutions in developing countries respond to particular international risk.
\end{abstract}

Keywords: financial sector, international risk, Jordan

\section{Introduction}

The Middle East and North Africa Region (MENA) is considered a high-risk region (COFACE, 2010). Part of the problem is attributed to the constant crises the region faces. The humanitarian crisis due to the constant political upheaval in Syria, Iraq, Yemen and Palestine has led to a refugee crisis for Lebanon and Jordan. Despite all of the challenges, the opportunities are immense for business. Financial sector, similar to other players in the business environment, is exposed to significant risk outside the traditional areas of credit risk and market risk. The financial sector in Jordan is bound to be influenced by such risks, as the industry is no longer insulated from global trends. Financial institutions should, therefore, have to examine and respond to the environment in which they operate. Financial institutions can, furthermore, develop policies in advance to cope with the possibility of international risk. Risk analysis, particularly of those of political substances, is typically used to identify possible future scenarios that might affect investment. In order to minimize the risks associated with investment, a way of controlling the risks should be included within the financial institutions' decision-making process.

The financial sector in Jordan, as reported by Ghafoor (2002), has been adversely affected by the political instability in the region of the MENA and that situation has resulted in heavy losses for operating financial institutions. Political instability and government intervention in business also contributed to the crisis. Despite this, risk studies have been mostly written within a North American and European context. Little attention has been directed to the international risk in developing countries, including Jordan. Although Jordan is viewed as one of the major players in the economically and politically volatile MENA region (Nasser et al., 1999), studies of the impact of international risk on financial sector have also been scarce. This paper represents one of the first such investigations in this area and aims to fill the information gap by analysing how financial institutions in Jordan respond to international risk.

This paper, accordingly, aims to contribute to the understanding of risk responses in developing countries through the exploration of the financial institutions' responses in Jordan. Based on this aim, the objectives of this 
paper are divided into three: a) to critically examine the international risk that affect the financial institutions; b) to identify those most significant according to their impact upon the financial institutions; and c) to examine the financial institutions' strategies and policies in dealing with those risks.

\section{Literature Review}

Jordan's economy, as reported by CIA World Facebook (2014), is among the smallest in the Middle East, with insufficient supplies of water, oil, and other natural resources underlying the government's heavy reliance on foreign assistance. Other economic challenges for the government include chronic high rates of poverty, unemployment, inflation, and a large budget deficit. Since assuming the throne in 1999, King ABDALLAH has implemented significant economic reforms, such as opening the trade regime, privatizing state-owned companies, and eliminating some fuel subsidies, which in the last decade spurred economic growth by attracting foreign investment and creating some jobs. The global economic slowdown and regional turmoil, however, have depressed Jordan's GDP growth, impacting export-oriented sectors, construction, and tourism. This suggests that the financial sector is exposed to more risks because the Government's visions of a more efficient economy would bring foreign competition.

\subsection{Financial Sector}

The beginning of the financial sector in Jordan goes back to 1925 when the first bank that started operation was the Ottoman Bank (Turkish) in Amman (Al-Khatib \& Gharaibeh, 1998). Following the Arab-Israeli war in 1948, the $\mathrm{AB}$ moved its main office from the Palestinian Territories to Jordan. Thus it became the nucleus of the local financial institutions in Jordan. Furthermore, the civil war in Lebanon (1974-1990) led to a transfer of many economic activities including banking from Lebanon to Jordan (Al-Rasheed, 1994). However, the majority of financial institutions were established at the end of 1960's and in 1970's/ 80's following the oil boom in the Arab Gulf States, which had a positive impact on the Jordanian economy. This was reflected in the financial aid from these states to Jordan and Jordanian migrants' remittances.

The government encouraged the expansion of banking services as a key to its economic development policy. Deposits were attracted from other Arab nations, and the savings and remittances of the many Jordanians who traditionally had never used financial institutions were captured. These deposits were in turn funneled as loans to growing companies that needed capital. To sum up, the financial sector is active in Jordan. It is one of the main pillars of the national wealth and it is pushing the whole economy forward. Financial institutions have the biggest percentage in the Amman stock exchange in comparison to the other sectors. This suggests that the financial sector plays a significant role in Jordan's economy. This also became as a motivation to conduct this paper since sustaining the development of the financial sector is needed.

The Central Bank of Jordan (CBJ) supervises the banking activity within the country, with the objectives and functions of maintaining monetary stability, ensuring Jordanian Dinar convertibility and promoting the sustained growth of the country's economy. In addition, the CBJ has effectively participated in the establishment of a number of financial institutions and corporations, such as Amman Stock Exchange, Jordan Mortgage Refinance Company, Jordan Loan Guarantee Corporation, and Deposit Insurance Corporation. All of which have played an important role in supporting economic development efforts in Jordan (CBJ, Annual Report, 2013). Financial institutions in Jordan fall into three main categories: banks; financial service institutions which carry out normal banking activities in accordance with Banking Law and regulations and insurance companies. To this end, the structure of financial sector in Jordan shows that financial institutions vary from multinational financial institutions to small national financial institutions. This suggests that these financial institutions would be affected in different ways by different risks. Thus, caution must be exercised when generalising risk responses amongst financial institutions and must be subjected to careful analysis in order to assess the full impact upon a particular institution.

\subsection{International Risk}

The literature on international risk has focused on two issues: a) the recognition of the existence of international risk and its likely consequences; and b) the development of policies to cope with this risk. Despite the fact that international risk poses severe threats and may create profitable opportunities for institutions, they have been found to view and react to this risk without formal planning or systematic analysis (Buckley, 1996). Such a formal assessment of international risk and its implications for institutions is crucial for decision-making.

Since the 1948 war, the subject of international risk has started to play a role in the MENA business scene. At the same time, a growing body of literature (e.g. Rice \& Mahmoud, 1990; Mortanges \& Allers, 1996, Al Khattab et al., 2011; Al Khattab et al., 2010; Al Khattab et al., 2007; Al Khattab et al., 2008a; Al Khattab et al., 2008b) 
suggested that international risk management could avoid or decrease the chance of both property and income losses. In a business environment, furthermore, uncertainty arises from the occurring situation that is known as the source of the risk. According to Buckley (1996), international risks, which impinge on an organisation, are often the source of the uncertainty. Essentially the risks the organisation faces arise from the political forces at work in the day-to-day operating environment. Hence, political instability has been cited as the largest source of uncertainty, which faces decision makers (Kennedy, 1987). Thus, recognising and coping with international risk is important to the development of a country's strategic sectors. This is particularly so for the financial sector in Jordan since it is a main pillar of the economic growth.

The concept of international risk, however, was used interchangeably and in a fragmented way. According to Mortanges \& Allers (1996), there has been little consensus on a definition of 'international risk' except that it includes a concentration on adverse governmental actions. The scope of the early definitions of the term was limited and led to inappropriate conceptualisation, wrong selection of data and misinterpretation of the results (Sethi \& Luther, 1986; Oseghale, 1993). The assumption that international risk necessarily exerts negative influences on a institution, moreover, is not always true (Fitzpatrick, 1983). Many researchers have challenged the assumption that the orientation of international risk is necessarily negative (e.g. Robock, 1971; Torre \& Neckar, 1988; Waring \& Glendon, 2001). According to Kanaan (2001), this would enhance productivity and the transfer of knowledge and expertise to the country, but although it might hinder the development of national Jordanian professionals.

Davies (2011) defined international risk as 'governmental or societal actions and policies, originating either within or outside the host country, and negatively affect either a select group of, or the majority of, foreign business operations and investment'. According to Mortanges and Allers (1996), this definition is more comprehensive since it contains a wide variety of risks, which may face business. For the purpose of this paper, Davies' (2011) definition is more appropriate because it provides a complete conceptualisation of international risk facing business in Jordan. The prior classification of international risk was also limited. The question of what factors to analyse depends upon researcher's understanding of the international risk. According to Kennedy (1987) they include internal rebellion, armed conflict, change in government, and government actions. Davies (2012) divided international risk to internal, external, social and governmental sources. Other researchers have also different classifications. For Jordan, and for the purpose of this study, the elements of the international risk investigated should include, at least, the following: discontinuities: e.g. drastic change in the Palestinian Territories.; uncertainty: e.g. unanticipated changes in Iraq, Syria, Iran, Yemen; international impact: e.g. WTO, IMF, and the U.S Free Trade Agreement; governmental impact: e.g. the enactment of a oil prices.

\subsection{The Impact of International Risk on Financial Sector}

According to Pollack (1988) the ultimate challenge for a risk manager when assessing international risks is to determine whether or not the event poses a threat to a institution's performance. The nature of risks varies most fundamentally by the country and the type of institutions because their exposures to international risk differ. For example, financial institutions are more likely to be affected by wars or strikes because customers may be reluctant to deposit their money in while direct investors tend to be affected more by industry or institution risks. Accordingly, it is important to pay due attention to political variables that affect the overall business environment. However, it is not an easy task to determine whether or not a political event poses threats to the financial sector, in particular, where the related literature is scarce. Therefore, an attempt was made to find out some indicators, which might be used to verify which risks are most relevant to the financial sector.

The first indicator is the foreign direct investment inflows (FDI). Pollack (1988) emphasised on the fact that foreign investment tends to react quickly on the economic and political situation prevailing in different countries and regions. Factors, which prompt foreign companies to enter particular countries, have been reported in various studies and in different ways. Dunning and Narula (1998) pointed out that international risks were considered the most important determinants in investment decision-making in banking. This reflects the belief that the volatility in the political environment increases the perceived risk and uncertainty experienced by financial institutions. In a paper prepared by the Jordanian Royal Scientific Society (1988) about the investment climate in Jordan, it was found that one of the most important problems and obstacles related to the investment climate was the influence of the political and economic situation in the region and its negative impact on attracting foreign and Arab investors.

The second indicator is the customers' deposit. Financial indicators may also be used to verify the significance of risk to the financial institutions' operations. According to Awwad (2003) the Second Gulf War in 1990 has exposed the financial institutions to a sharp decrease in their customers' deposits. This was because the 
customers have been withdrawing their deposits from operating financial institutions since the early days of the war. Furthermore, the same war has resulted in an increase demand on the foreign currency. Accordingly, customers' deposits and financial institutions' deposits may indicate the extent to which a particular risk is significant to a bank.

\subsection{International Risk Management Strategies}

Financial institutions can develop policies in advance to cope with the possibility of international risk. Risk analysis, particularly those of political substances, is typically used to identify possible future scenarios, which might affect the investment. In order to minimise the risks associated with investment, a way of controlling the risk must be included within the decision making process. International risk analysis is used in investment analyses to screen out countries that are excessively risky or to monitor countries in which a company is currently operating so as to determine whether new policies are needed (Shapiro, 1999). Consequently, financial institutions should have been developed policies in advance to cope with the potential risks in their environment. Given the recognition of risky international risks, institutions can follow at least four separate, but not necessarily mutually exclusive, strategies (Buckley, 1996; Shapiro, 1999). These include: avoidance; insurance; negotiating the environment; and structuring the investment.

The easiest way to manage political is to avoid it, and many institutions do so by screening out investments in politically uncertain countries (Shapiro, 1999). According to Buckley (1996), the main issue therefore is the degree of international risk a company is willing to tolerate and the return required to bear it. The another strategy is buying insurance policy. This strategy is one of the oldest and most commonly used strategies to offset risk (Kennedy, 1987). Insuring assets in politically risky areas allow financial institutions to concentrate on managing the business rather than worrying about international risk. Institutions can also seek an understanding with the host government before undertaking the investment, defining rights and responsibilities of both parties. This strategy seems to be less effective to financial institutions since financial services are operating now under international conventions. Nevertheless, institutions operating in an unstable environment often seek to minimise their exposure to international risk by increasing the host government's cost of interfering with company operations. According to Shapiro (1999), this action involves adjusting the operating policies and the financial policies to closely link the value of the foreign project to the multinational institution's continued control. In the financial sector, in particular, operating policies may also be resorted to as a ploy to avoid international risk. These include: short-term profit maximisation; developing local stakeholders; and merger and acquisition.

\section{Research Methodology}

The choice of a research philosophy is critical because it has important implications on the choice of methodology and the methods of data collection (Hussey et al., 1997). Two main approaches dominate the literature in business and management research: positivism and phenomenology. In line with the aim of this paper, with a small sample of subjects, the phenomenology approach was used. Investigating such a new topic, and on which there is little existing literature, needs the inductive approach. According to Creswell (1998), the inductive approach is more appropriate to generate data and analyse and reflect on what theoretical themes the data are suggesting. In the case of Jordan, information on financial institutions' practices has not been made public. Financial institutions are also cautious about what their competitors know about their risk strategies and policies. As this paper investigates cases, which are different in certain key ways, case studies are used in order to make comparisons, build theory, or propose generalisations. The entire target population of the 64 financial institutions which are listed at Amman Stock Exchange for the year 2013 has been studied.

Data for such a study, according to Yin (1994), can be originated from six different sources, documents, direct observations, participant observations, archival records, interviews and physical artefacts. Secondary data is served as a basis for understanding of the investigated problems. Such data resources are: annual reports, article databases, financial institutions' websites and books. The financial institutions' annual reports were used during the period 1998 to 2013 because the attempts to attain the reports prior this date were not successful. Interviews were also used. The use of interviews can help researchers to formulate and gather data that are relevant to their research questions and objectives. This justifies the use of interviews as principal tool for collecting empirical data. For the purpose of this paper, semi-structured interviews were used to identify factors that affected the financial institutions. The responses were sought for the following general questions: a) what international risk over the last 10 years have generally affected the financial sector in Jordan?; b) which risks over the last 10 years have particularly affected the financial institutions' deposits?; and c) how have the financial institutions responded to these risks? Three interviews were conducted with representatives from the 28 financial 
institutions.

\section{Findings}

The exposure to risk can determine the institution's responses. different strategies and policies were used by the financial institutions in dealing with different risks. Due to the fact that this research is the first of its kind, it is necessary to view the findings as in nature. Since the Second Gulf War in 1990, the political instability has prevailed in many countries in the MENA. The financial institutions, as a response, stayed away from those considered to be politically unstable. Furthermore, financial institutions find it hard to obtain official approval to establish branches in the Gulf States, which has resulted in little presence of the financial institutions in these countries. The issue of the bank's willing to tolerate and the return required to bear international risk plays an important role in avoidance strategy. Since 1999, on the other hand, the financial institutions tend to expand externally rather than internally. This behaviour aimed to diversify their markets, and operating environments in order to lower the potential exposure to the high level of political instability of Jordan.

This finding is consistent with Gizycki's (2001) findings who argued that financial institutions in seeking to maximise efficiency in making loans and related customer-servicing activities, tend to focus on geographical areas where they believe they have a comparative advantage. However, the financial institutions' strategy of avoiding countries likely to be politically unstable ignores the possible high return available from investment there since business is all about taking risks and ensuring that sufficient returns are earned to compensate for them. There has been only two cases of financial institutions with regard to the use of international risk insurance as an investment strategy. This finding is consistent with the Mortanges and Allers's (1996) finding who argued that international risk insurance is the least used strategy by Dutch financial institutions. The possible reasons for not insuring international risk could be that such insurance is expensive and the financial institutions have little presence in countries facing critical problems. Since the financial institutions are trading in unstable environment, it is important that they realise that protection against some international risk is available. International risk insurance cannot be a panacea for every conceivable international risk that can confront financial institutions. But in the volatile MENA, obtaining international risk insurance can make the difference between operating a profitable business and making a costly mistake.

It could be argued that because such a strategy has little weight; other financial institutions have followed different strategies. Some banks have entered Algeria through establishing joint financial institutions. This finding is in line with Shapiro's (1996) finding who argued that, because these agreements carry little weight and high rate of obsolescence, financial institutions pursued more active strategies of risk management. The financial institutions developed external financial stakeholders in the venture's success as a defensive strategy against the regional political instability. This strategy includes investing U.S dollar denominated certificates of deposit of medium maturity dates. Differences in financial institutions types and activities affect their ways of developing such financial stakeholders. By adopting this strategy, the financial institutions not only can spread risks but also elicit an international response to any expropriation move or other adverse actions by a government.

Since the Second Gulf War in 1990, the financial institutions have adopted tight lending policies in Jordan as well as in the Palestinian Territories as a response to the regional uncertainties, which have prevailed in the MENA, including Jordan. Since the beginning of the Arab Spring in 2010, the financial institutions tightened these facilities further and became more selective. This finding is in line with Buckley (1996) who suggested that institutions can respond to international risk by maximising cash generating for the short-term, regardless of the effect of such actions on long-term profitability. As consequence of this strategy, credit facilities were forwarded to projects that would boost growth. However, these policies have helped the financial institutions in warding-off the high risks associated with lending activities under such circumstances.

However, most of the loans were forwarded to the commerce sector and most of their activities were carried out in a limited area of retail banking services. This trend reflects the fact that financial institutions have a short-term lending strategy. In the meantime, as reported by Jordanian Ministry of Industry, long-term loans were needed for more industry and manufacturing activities. Furthermore, the financial institutions have lent more in local currency than foreign currency. The reason could be attributed to the Central Bank of Jordan's foreign exchange policy, which continued to rely on the JOD peg against the U.S dollar at a mid rate of 0.709 . This was considered as a challenge facing local currency since most loans were in local currency. The implications are worse because small projects dominate Jordan's economy. Meanwhile the financial institutions are reluctant to lend to these small enterprises in order to avoid any risk related to bad debt. Such practice introduced an inadequate financing of small projects (MOI, 2001).

Despite the many international risk, which have been discussed earlier, they have not motivated the financial 
institutions to merge. institutions may prefer $\mathrm{M} \& \mathrm{~A}$ in order to reduce its per unit cost by using excess capacity or spreading fixed costs across more units (Azzam, 2002). For financial institutions, M\&A could be for good or ill, depending on whether or not they promote competition and improve performance. This means either the M\& A strategy is not sound response to deal with those risks or it is but hindered by political or family reasons. The structure of the financial institutions as a family business supports the above idea. This finding is consistent with Azzam (2002) who pointed out that the MENA is significantly lacking in any M\&A activity, largely for political and family reasons. The all case financial institutions' management of their liquidity positions since the Arab Spring was heavily influenced by preparations for the sharp increase in the public's demand for cash as uncertainty in financial markets increased. To summarise, the financial institutions lack clear long-term investment policies. Their current responses are not effective in the medium and long term. This is because such responses lead to no substantial effect on the size of credit facilities. The political instability of the region, furthermore, played a role of hindering the financial institutions in playing the role of modern intermediaries. Given the current responses, the financial institutions should re-evaluate their current strategies since business is all about taking risks.

\section{Conclusions, Limitations and Implications}

This paper has been concerned with the international risk that affected the financial sector in Jordan and how financial institutions responded to such risks. Many international risks have faced financial sector, including the Second Gulf War, the $11^{\text {th }}$ September event; international financial crisis and the Arab Spring. Differences among the financial institutions in risk exposure to these risks arise from the differences of financial institutions' scope and scale. The financial sector's global operations have been affected by world economic activities, which showed serious downturns, decline interest rates in the money market, and weaken stock market indices. The potential increased competition has minimised the market share of the financial institutions forcing them to increase risk exposure in order to compensate for diminishing returns. Thus, these risks have different impact on different financial institutions. This suggests that generalising risks' impact upon financial institutions must be used cautiously and must be subjected to careful analysis in order to assess the full impact upon a particular bank. Following this, financial institutions' specific characteristics played an important role in the type and the level of perceived risk, which, in turn, affected the strategy used to deal with a particular event.

Another finding relates to the classification of those risks affecting the financial institutions. These risks can be categorised into two categories: a) risks affecting all financial institutions and b) risks affecting particular financial institutions. This suggests that those risks have both positive and negative impact upon the financial sector. Foreign financial institutions, meanwhile, have more opportunities to expand since the accession eliminates barriers to bilateral trade in services. This also suggests that risk assessment should consider such positive developments, which represent opportunities for business and not only the negative consequence. In this context, despite these two risks might force some of the national financial institutions to be forced out of business, but it may positively affect the industry. This is because the cost efficiency and product mix of large U.S financial institutions might motivate national financial institutions to improve the quality and mixture of its services.

The exposure to different risks have led to differences in financial institutions' responses either. The analysis indicated that the financial institutions stayed away from countries considered to be politically unstable (e.g. Iraq, Libya, Iran, and Sudan). This suggests that the financial institutions' avoidance strategy ignores the possible high return available from investment and they miss the opportunities to be first movers into those countries. Although some risks that face the financial institutions are insurable but international risk insurance was the least used strategy by the financial institutions. However, international risk insurance cannot be a panacea for every conceivable risk that can confront financial institutions. But in such a volatile environment, obtaining international risk insurance can make the difference between operating a profitable business and making a costly mistake. Similarly, negotiating the environment strategy has also the least weight among the financial institutions because such concession agreements do not guarantee the bank avoidance of international risk. With regard to structuring the investment strategy, the financial institutions developed internal and external financial stakeholders in the venture's success as a defensive strategy. The larger financial institutions are more likely to involve other financial institutions. To sum up, the financial institutions lack clear long-term investment policies. Their current responses are not effective in the medium and long term. This is because such responses lead to no substantial effect on the size of their activities. Furthermore, the financial institutions have to be aware of potential risks inherent when operating in unstable environments.

The simple analysis presented in this paper provides a first attempt at verifying the relevance of particular risks to the financial sector. The relatively small data available, in terms of the number of financial institutions 
constrained the scope of empirical analysis. Such simplistic analysis, fails to address the interaction between financial institutions' responses and individual-institution effects, and as a result is likely to understate the effect of those risks on financial institutions' operations. Therefore, the inclusion of institution-specific variables, such as bank size, credit destination, customers' characteristics into the modelling framework would allow a more complete investigation of the relative contribution of individual-bank characteristics and movement in macroeconomic variables on overall institution strategies in dealing with risk.

Despite that the contribution of this paper lies in the enhancement of risk practices in banking under uncertainty, yet international risk theory, which some risks are deduced, is based on developed countries literature. Therefore, it is not totally independent of the cultural context. The paper does not meet the demands for a complete theoretical sampling. Further research, therefore, has to continue to sample until each of the studies categories are saturated, or else the theory will be lacking density and precision. It is likely that further insights on how financial institutions in developing countries respond to particular risks can be gained from a more detail paper of the financial institutions. As risks have a different impact on different institutions, the generalisation of responses amongst financial institutions must be used cautiously and subjected to careful analysis in order to assess the full impact upon a particular bank.

\section{References}

Al Khatib, F., \& Gharaibeh, H. (1998). Service quality: Bank customers' expectations and perceptions in Jordan. Dirasat- Administrative Sciences, 25(1), 199-210.

Al Khattab, A., Aldehayyat, J., \& Stein, W. (2010). Informing country risk assessment in international business. International Journal of Business and Management, 5(7), 54-62.

Al Khattab, A., Anchor, J. R., \& Davies, E. (2007). Managerial perception of political risks in international $\begin{array}{lllll}\text { projects. International Journal of Project Management, 25(7), 734-743. } & \text {. }\end{array}$ http://dx.doi.org/10.1016/j.ijproman.2007.03.006

Al Khattab, A., Anchor, J. R., \& Davies, E. (2008a). Managerial practices of political risk assessment in Jordanian international business. Risk Management: An International Journal, 10(2), 135-152.

Al Khattab, A., Anchor, J. R., \& Davies, E. (2008b). The institutionalisation of political risk assessment (IPRA) in Jordanian international institutions. International Business Review, 17, 688-702. http://dx.doi.org/10.1016/j.ibusrev.2008.09.007

Al Khattab, A., Awwad, A., Anchor, J. R., \& Davies, E. (2011). The use of political risk assessment techniques in Jordanian multinational corporations. Journal of Risk Research, 14(1), 97-109. http://dx.doi.org/10.1080/13669877.2010.505346

Al-Shaikh, F., \& Al-Shammari, M. (1995). The application of quantitative analysis techniques in Jordan manufacturing organisations. Abhath Al-Yarmouk: Human and Social. Science, 11(2), 63-75.

ASE. (2013). Amman Stock Exchange, Amman, Jordan.

Awwad, R. (2003). Financial sector in Jordan. Derasat: Scientific Studies, (39), 14-21.

Azzam, G. (2002). Mergers in financial institutions. Abhath Al-Yarmouk: Human and Social Science, 10(1), 13-17.

Buckley, A. (1996). Multinational finance (3rd ed.). London: prentice Hall.

CBJ. (2012). Annual Report 2012. Central Bank of Jordan, Amman, Jordan.

CBJ. (2013). Annual Report 2013. Central Bank of Jordan, Amman, Jordan.

CIA World Factbook. (2014). Jordan Economy Profile for the year 2014.

Creswell, J. (2008). Qualitative inquiry and research design. Sage publication.

Davies, R. (2011). International risk and banking industry. Journal of Business and Economy, 7(1), 54-61.

Ghafoor, A. (2002). The name of the game. Derassat, 4(2), 12-14.

Gizycki, M. (2001). The effect of macroeconomic conditions on financial institutions. Research Discussion Paper, 2001-06, Reserve Bank of Australia.

Hussey, J., \& Hussey, R. (2004). Business research: A practical guide for undergraduate and postgraduate students. Palgrave: Basingstoke.

Kannan, T. (2010). Impact of Jordan - USA free trade agreement on financial sector. Arab Bank Review, 3(2), 
45-54.

Mortanges, G., \& Allers, V. (1996). International risk assessment: Theory and the experience of Dutch institutions. International Business Review, 5(3), 303-318. http://dx.doi.org/10.1016/0969-5931(96)00012-1

Rice, G., \& Mahmoud, E. (1990). International risk forecasting by Canadian institutions. International Journal of Forecasting, 6(1990), 89-102. http://dx.doi.org/10.1016/0169-2070(90)90100-P

Shapiro, A. (1981). Managing international risk: A policy approach. Columbia Journal of World Business, Fall, 63-70.

Shapiro, A. (1999). Multinational financial management (6th ed.). New Jercy: Prentice Hall.

Waring, A., \& Glendon, A. L. (1998). Managing risk: Critical issues for survival and success into the 21 st century (3rd ed.). London: Thomson Learning.

Yin, R. (1994). Case Paper Research: Design and Methods (2nd ed.). London: Sage Publications.

\section{Copyrights}

Copyright for this article is retained by the author(s), with first publication rights granted to the journal.

This is an open-access article distributed under the terms and conditions of the Creative Commons Attribution license (http://creativecommons.org/licenses/by/3.0/). 